\title{
The Impact of the Covid-19 Pandemic on the Educational Work of Kindergarten Teachers
}

\author{
Časlav Stoiljkovićn ${ }^{*}$ \\ ${ }^{1}$ Academy of Professional Studies Southern Serbia, Department of Teacher Education - Bujanovac, Serbia, \\ e-mail: stcaslav@gmail.com
}

\begin{abstract}
The purpose of this paper is to consider the impact of the Covid-19 pandemic on the educational process from the perspective of kindergarten teachers. There is not enough research on the effects that the pandemic has caused in educational work with young children. The paper aims at better understanding of the realization of educational work during the state of emergency in Serbia, which came as a consequence of the unfavorable epidemiological situation. Teachers, children and parents are recognized in the paper as key determinants of educational quality. The results of the assessment of the attitudes of 168 teachers in Serbia on important aspects of the educational process during the state of emergency were statistically processed. Based on the obtained results, conclusions were made that show a sufficient degree of adaptability of teachers to the new situation as well as a significant role of teachers as factors of stability of educational work. The results emphasize a high degree of positive attitudes when it comes to cooperation between teachers and parents. The results show that there is a lot of room for improving the quality of educational work at a distance.
\end{abstract}

Keywords: child, teacher, parents, educational work, Covid-19.

\section{Introduction}

The age in which the planet has quickly been ruled by the unseen, the unexpected master of uncertainty, master of changes in human lives and testing of their universal action, brings us new challenges. The unfavorable epidemiological situation caused by Covid-19 forced us to stop in the process of striving for rapid development, testing our flexibility both personally and professionally.

The state of emergency in Serbia lasted from March 15 to May 6, 2020. With the recommendation of the crisis headquarters, the kindergartens started working on May 11, while respecting the security aspects that have been determined. Along with the closure of preschool institutions, social distancing was also recommended, which was followed by a periodic curfew, or a quarantine. Examining the psychological impact of quarantine on people, the authors (Brooks et al., 2020) cite quarantine duration, fear of infection, feelings of frustration and boredom, inadequate supplies, and inadequate information as potential stressors during quarantine.

The period of the state of emergency brought with it an emergency situation in the educational work. Teachers had a changed role, the role which required increased adaptability, online communication with parents and children and online realization of educational tasks. The sudden transition to this way of working due to the unfavorable epidemiological situation was realized without prior preparation, analysis and adequate period of adaptation to the new situation. UNICEF data on the analysis of interactive relations between teachers and parents and children in Serbia show that $40 \%$ of parents and guardians of children under 6 were in constant contact with teachers, and $14 \%$ of them made that contact periodically. The value of these relationships is reflected in the qualitative aspect of that communication. Within the group of parents who had contact with teachers, $86 \%$ stated that they received instructions related to organizing and implementing games and activities with children, $48 \%$ of them answered that they received advice from teachers, and $33 \%$ of them had only communication related to elementary things related to the child (UNICEF, 2020).

When it comes to supporting children through educational programs, most parents are of the opinion that children have not received the full support that is otherwise legally guaranteed. (NEPC, 2020) In support of this are the results of research in America which show that children did not receive the support they needed, while parents received online support but it was quite minimal. (NIEER, 2020) 
Research (Barnet and Jung, 2020) shows that only 10\% of children were involved in distance activities on a daily basis after kindergartens had closed, and that online work could not replace the educational work that takes place on the premises of the institution. The authors suggest that it is necessary to improve the online way of working with the aim of daily engagement of children in activities, as well as to include training for parents. In such an unplanned situation, one of the challenges in working with children is to maintain the continuity of children's development. One of the problems may be that „, numerous developing countries are still encountering barriers in enjoying E-learning as internet connectivity is a major problem" (Gyimah, 2020).

In modern analyses, the guidelines necessary for the adequate and quality educational work of teachers are of ethical nature and are an important factor in maintaining and empowering the educational process. Regarding the requirements that are set and whose basis is in ethics, the following ones stand out: responsibility towards children, responsibility towards families, responsibility towards colleagues, responsibility towards the community and society (Muller and Baum, 2020).

Priorities of children's development are determined by the respect for the principles of accessibility, democracy, openness, authenticity, development (Law on Preschool Education). Adherence to these principles is largely limited by the negative epidemiological situation. The OMEP report states that the pandemic affected the ability to meet children's needs and affected the most important children's needs. Fulfillment of these needs is the basis for children's proper development, and they are: "need to play, move, and relate with their peers" (OMEP, 2020, 120). Research (Bao, Qu, Zhang, and Hogan, 2020) found that kindergarten closures will reflect on the reduction in children's literacy by $67 \%$, and as an attempt to alleviate this process the authors recommend daily reading of books to children. This is one of the bad effects of kindergarten closures. Such results agree with the research results that show ,,positive evidence that watching a video of book reading or reading over video chat can be an educational, engaging activity for children during the pandemic and beyond" (Gaudreau et al., 2020, 14).

\section{Materials and Methods}

The aim of the research is to determine the attitudes of teachers to the influence of Covid-19 on the educational work of teachers during a state of emergency.

For the purposes of the research, a descriptive method was used. For data collection, a scaling technique was used as an instrument scale for estimating the Likert type of 16 statements. The level of agreement with the statement was determined by circling the numbers with the following descriptions: 1 (No, not at all), 2 (Mostly not), 3 (I am undecided), 4 (Mostly yes), 5 (Yes, completely). There are three groups of claims within the instrument. The first group of claims refers to the examination of the impact of the pandemic on the personality of the teacher and their educational work (from 1 to 5). The second group of claims refers to the examination of the cooperation of teachers with parents during the state of emergency (from 6 to 9). The third group of claims examines the attitudes of teachers to the impact of the pandemic on the developmental process of children (from 10 to 16). The effort was to determine the attitudes of teachers to the possible factors that are important for educational work during a state of emergency.

One hundred and seventy-one assessment scales were distributed, of which 3 were inadequately completed and were not included in the data processing. Data processing was done on the basis of 168 completed assessment scales. The sample consisted of teachers from different parts of Serbia. Average number of years of work experience of respondents was 13.6. The research was conducted during the month of September 2020.

\section{Results}

Interpretation of the results is based on the analysis of three key factors in the educational process: the attitudes of teachers to changes in educational work during the state of emergency, the attitudes of teachers to the cooperation with parents, the attitudes of teachers to the impact of impossibility of physical attendance on children's development. 
Table 1

I am handling well the changes in educational work caused by Covid-19

\begin{tabular}{|c|c|c|c|c|c|}
\hline & & Frequency & Percent & Valid Percent & $\begin{array}{c}\text { Cumulative } \\
\text { Percent }\end{array}$ \\
\hline \multirow{6}{*}{ Valid } & No, not at all & 4 & 2,4 & 2,4 & 2,4 \\
\hline & Mostly not & 14 & 8,3 & 8,3 & 10,7 \\
\hline & I am undecided & 24 & 14,3 & 14,3 & 25,0 \\
\hline & Mostly yes & 88 & 52,4 & 52,4 & 77,4 \\
\hline & Yes, completely & 38 & 22,6 & 22,6 & 100,0 \\
\hline & Total & 168 & 100,0 & 100,0 & \\
\hline
\end{tabular}

Adaptability to change as an important factor of educational work puts the teacher in a position of continuous active state. Teachers see themselves as professionals who have managed to adapt to the changes in educational work caused by the pandemic, because $75 \%$ of teachers believe that they have handled the changes in a good way whereas $14.3 \%$ of the respondents were undecided about this statement, and $10.7 \%$ had a negative opinion.

Table 2

The educational work during the state of emergency was of high quality and efficient

\begin{tabular}{llrrrr}
\hline & Frequency & Percent & Valid Percent & $\begin{array}{c}\text { Cumulative } \\
\text { Percent }\end{array}$ \\
\hline \multirow{4}{*}{ Valid } & No, not at all & 8 & 4,8 & 4,8 & 4,8 \\
& Mostly not & 34 & 20,2 & 20,2 & 25,0 \\
& I am undecided & 40 & 23,8 & 23,8 & 48,8 \\
& Mostly yes & 62 & 36,9 & 36,9 & 85,7 \\
& Yes, completely & 24 & 14,3 & 14,3 & 100,0 \\
& Total & 168 & 100,0 & 100,0 & \\
\hline
\end{tabular}

When it comes to the quality of educational work with children during the state of emergency, opinions are divided with $51.2 \%$ of teachers having a positive attitude to the quality of that process, while $23.8 \%$ of them are undecided. A quarter of the surveyed teachers, $25 \%$ of them, with a negative attitude to the quality and efficiency of educational work during the state of emergency, leads us to believe that there is a lot of room for improvement in this process.

Table 3

During the state of emergency, my share in family responsibilities increased, which negatively affected my professional work

\begin{tabular}{llrrrr}
\hline & Frequency & Percent & Valid Percent & \multicolumn{2}{c}{$\begin{array}{c}\text { Cumulative } \\
\text { Percent }\end{array}$} \\
\hline \multirow{4}{*}{ Valid } & No, not at all & 46 & 27,4 & 27,4 & 27,4 \\
& Mostly not & 56 & 33,3 & 33,3 & 60,7 \\
& I am undecided & 18 & 10,7 & 10,7 & 71,4 \\
& Mostly yes & 30 & 17,9 & 17,9 & 89,3 \\
& Yes, completely & 18 & 10,7 & 10,7 & 100,0 \\
& Total & 168 & 100,0 & 100,0 & \\
\hline
\end{tabular}

The tendency to examine whether family obligations that reduce the quality of professional work of teachers increased during the state of emergency resulted in $60.7 \%$ of surveyed teachers not having such a share of family responsibilities, $10.7 \%$ of teachers were undecided and $28.6 \%$ of them had additional family obligations during the state of emergency, which negatively affected their professional work. Slightly 
more than a quarter of the respondents linked family obligations to the quality of professional work.

Table 4

I needed professional support in performing work tasks during a state of emergency

\begin{tabular}{llrrrr}
\hline & Frequency & Percent & Valid Percent & $\begin{array}{c}\text { Cumulative } \\
\text { Percent }\end{array}$ \\
\hline \multirow{6}{*}{ Valid } & 20 & 11,9 & 11,9 & 11,9 \\
& Mostly not & 86 & 51,2 & 51,2 & 63,1 \\
& I am undecided & 22 & 13,1 & 13,1 & 76,2 \\
& Mostly yes & 22 & 13,1 & 13,1 & 89,3 \\
& Yes, completely & 18 & 10,7 & 10,7 & 100,0 \\
& Total & 168 & 100,0 & 100,0 & \\
\hline
\end{tabular}

On the claim of the need for professional support, $63.1 \%$ of teachers did not need such help, $13.1 \%$ were undecided and $23.8 \%$ needed professional help. The problems that create such needs have not been investigated.

Table 5

During the state of emergency, my colleagues helped me to overcome the problems in practice

\begin{tabular}{llrrrr}
\hline & Frequency & Percent & Valid Percent & $\begin{array}{c}\text { Cumulative } \\
\text { Percent }\end{array}$ \\
\hline \multirow{6}{*}{ Valid } & & 6 & 3,6 & 3,6 & 3,6 \\
& Nostly not & 22 & 13,1 & 13,1 & 16,7 \\
& I am undecided & 14 & 8,3 & 8,3 & 25,0 \\
& Mostly yes & 94 & 56,0 & 56,0 & 81,0 \\
& Yes, completely & 32 & 19,0 & 19,0 & 100,0 \\
& Total & 168 & 100,0 & 100,0 & \\
\hline
\end{tabular}

The collegiality of teachers during the state of emergency remained at a high level. This is confirmed by the established results that $75 \%$ of teachers had the support of their colleagues in solving the problems they faced. $8.3 \%$ of them were undecided, while $16.7 \%$ did not receive the support of their colleagues.

Table 6

During the state of emergency, I had additional engagements and contacts with parents and children beyond the time provided for that

\begin{tabular}{llrrrr}
\hline & Frequency & Percent & Valid Percent & \multicolumn{2}{c}{$\begin{array}{c}\text { Cumulative } \\
\text { Percent }\end{array}$} \\
\hline \multirow{4}{*}{ Valid not at all } & 16 & 9,5 & 9,5 & 9,5 \\
& Mostly not & 12 & 7,1 & 7,1 & 16,7 \\
& I am undecided & 4 & 2,4 & 2,4 & 19,0 \\
& Mostly yes & 72 & 42,9 & 42,9 & 61,9 \\
& Yes, completely & 64 & 38,1 & 38,1 & 100,0 \\
& Total & 168 & 100,0 & 100,0 & \\
\hline
\end{tabular}

The state of emergency, in addition to preventing the physical attendance at preschool institutions and establishing an online way of working as an alternative solution, also introduced flexible working hours. In that sense, the vast majority of teachers, $81 \%$ of them had additional activities with parents and children outside the scheduled working hourswhile $2.4 \%$ of the respondents were undecided, and $9.5 \%$ performed online activities exclusively during the scheduled working hours. 
Table 7

Parents followed and accepted my guidance and counseling when it comes to educational work with children during the state of emergency

\begin{tabular}{llrrrr}
\hline & Frequency & Percent & Valid Percent & $\begin{array}{c}\text { Cumulative } \\
\text { Percent }\end{array}$ \\
\hline \multirow{2}{*}{ Valid } & 2 & 1,2 & 1,2 & 1,2 \\
& No, not at all & 10 & 6,0 & 6,0 & 7,1 \\
& Mostly not & 6 & 3,6 & 3,6 & 10,7 \\
& Mostly yes & 100 & 59,5 & 59,5 & 70,2 \\
& Yes, completely & 50 & 29,8 & 29,8 & 100,0 \\
& Total & 168 & 100,0 & 100,0 & \\
\hline
\end{tabular}

One of the symbols of quality educational work is the cooperation between parents and teachers. During the state of emergency, the role of parents is unavoidable, and the claim of following the instructions given by the teachers has a high level of consent. As many as $89.3 \%$ of teachers believe that parents accepted the guidance and counseling they received whereas $3.6 \%$ of them were undecided and $7.2 \%$ believe that parents did not accept and follow the instructions of the teachers.

Table 8

The cooperation between teachers and parents during the state of emergency was at a high level

\begin{tabular}{llrrrr}
\hline & Frequency & Percent & Valid Percent & \multicolumn{2}{c}{$\begin{array}{c}\text { Cumulative } \\
\text { Percent }\end{array}$} \\
\hline \multirow{2}{*}{ Valid } & Mostly not & 8 & 4,8 & 4,8 & 4,8 \\
& I am undecided & 16 & 9,5 & 9,5 & 14,3 \\
& Mostly yes & 104 & 61,9 & 61,9 & 76,2 \\
& Yes, completely & 40 & 23,8 & 23,8 & 100,0 \\
& Total & 168 & 100,0 & 100,0 & \\
\hline
\end{tabular}

The results of the previous statement are supported by a high degree of satisfaction with the cooperation between teachers and parents during the state of emergency. The vast majority of teachers, $85.7 \%$ of them had a positive attitude to the quality of cooperation with parents, $9.5 \%$ of them were indecisive, and $4.8 \%$ of teachers show negative experiences.

Table 9

I believe that the parents adequately compensated for the educational effect that the teachers could not provide live to the children during the state of emergency

\begin{tabular}{llrrrr}
\hline & Frequency & Percent & Valid Percent & $\begin{array}{c}\text { Cumulative } \\
\text { Percent }\end{array}$ \\
\hline \multirow{4}{*}{ Valid } & No, not at all & 16 & 9,5 & 9,5 & 9,5 \\
& Mostly not & 20 & 11,9 & 11,9 & 21,4 \\
& I am undecided & 52 & 31,0 & 31,0 & 52,4 \\
& Mostly yes & 72 & 42,9 & 42,9 & 95,2 \\
& Yes, completely & 8 & 4,8 & 4,8 & 100,0 \\
& Total & 168 & 100,0 & 100,0 & \\
\hline
\end{tabular}

Changes in the roles of parents and teachers have influenced the necessary existence of mutual cooperation. In an effort to determine whether parents have succeeded in compensating for the educational effect that teachers provide to children when they work in a regular way, opinions are divided and only 
$4.8 \%$ of teachers believe that parents can do it completely while $42.9 \%$ of them think parents can mostly do it. The percentage of undecided teachers is $31 \%$ while $21.4 \%$ believe that the parents could not compensate for the educational influence of teachers.

\section{Table 10}

The impossibility of physical presence of children in the preschool institution during the state of emergency had a negative impact on the continuous development of children

\begin{tabular}{|c|c|c|c|c|c|}
\hline & & Frequency & Percent & Valid Percent & $\begin{array}{c}\text { Cumulative } \\
\text { Percent }\end{array}$ \\
\hline \multirow{6}{*}{ Valid } & No, not at all & 8 & 4,8 & 4,8 & 4,8 \\
\hline & Mostly not & 32 & 19,0 & 19,0 & 23,8 \\
\hline & I am undecided & 22 & 13,1 & 13,1 & 36,9 \\
\hline & Mostly yes & 80 & 47,6 & 47,6 & 84,5 \\
\hline & Yes, completely & 26 & 15,5 & 15,5 & 100,0 \\
\hline & Total & 168 & 100,0 & 100,0 & \\
\hline
\end{tabular}

Online educational work with preschool children has its own specifics. The majority of teachers, $63.1 \%$ of them, believe that the impossibility of attending preschool has a negative impact on children's continuous development while $13.1 \%$ of them are undecided and $23.8 \%$ have negative attitudes to this statement.

Table 11

The change in the way of work caused by Covid-19 negatively affects the achievements of children

\begin{tabular}{llrrrr}
\hline & Frequency & Percent & Valid Percent & $\begin{array}{c}\text { Cumulative } \\
\text { Percent }\end{array}$ \\
\hline \multirow{6}{*}{ No, not at all } & 10 & 6,0 & 6,0 & 6,0 \\
& Mostly not & 40 & 23,8 & 23,8 & 29,8 \\
& I am undecided & 24 & 14,3 & 14,3 & 44,0 \\
& Mostly yes & 40 & 23,8 & 23,8 & 67,9 \\
& Yes, completely & 54 & 32,1 & 32,1 & 100,0 \\
& Total & 168 & 100,0 & 100,0 & \\
\hline
\end{tabular}

Regarding the impact of the way of working during the pandemic on the achievements of children, the majority of teachers, $55.9 \%$ believe that this way of working can have negative elements when it comes to the achievements of children whereas $14.3 \%$ are undecided, and $29.8 \%$ believe that the achievements of children will not be affected by the new way of working during the state of emergency.

Table 12

Break and inability to attend preschool can have a neqative impact on children's social development

\begin{tabular}{rlrrrr}
\hline & Frequency & Percent & Valid Percent & \multicolumn{2}{c}{ Cumulative } \\
& & & & & Percent \\
\hline \multirow{6}{*}{ Valid } & No, not at all & 8 & 4,8 & 4,8 & 4,8 \\
& Mostly not & 18 & 10,7 & 10,7 & 15,5 \\
& I am undecided & 24 & 14,3 & 14,3 & 29,8 \\
& Mostly yes & 48 & 28,6 & 28,6 & 58,3 \\
& Yes, completely & 70 & 41,7 & 41,7 & 100,0 \\
& Total & 168 & 100,0 & 100,0 & \\
\hline
\end{tabular}

A large number of teachers, $70 \%$ of them believe that the social development of children can have negative consequences due to the inability to physically attend preschool while $14.3 \%$ of them were undecided and $15.5 \%$ of teachers disagreed with this statement. 
Table 13

Break and inability to attend preschool can have a negative effect on children's moral development

\begin{tabular}{llrrrr}
\hline & Frequency & Percent & Valid Percent & \multicolumn{2}{c}{$\begin{array}{c}\text { Cumulative } \\
\text { Percent }\end{array}$} \\
\hline \multirow{4}{*}{ Valid } & No, not at all & 10 & 6,0 & 6,0 & 6,0 \\
& Mostly not & 26 & 15,5 & 15,5 & 21,4 \\
& I am undecided & 36 & 21,4 & 21,4 & 42,9 \\
& Mostly yes & 52 & 31,0 & 31,0 & 73,8 \\
& Yes, completely & 44 & 26,2 & 26,2 & 100,0 \\
& Total & 168 & 100,0 & 100,0 & \\
\hline
\end{tabular}

When it comes to moral development of children, $57.2 \%$ of teachers believe that physical nonattendance at a preschool institution negatively affects their moral development, $21.4 \%$ are indecisive and $21.5 \%$ do not agree with this statement.

Table 14

Break and inability to attend preschool can have a bad effect on children's physical development

\begin{tabular}{llrrrr}
\hline & Frequency & Percent & Valid Percent & $\begin{array}{c}\text { Cumulative } \\
\text { Percent }\end{array}$ \\
\hline \multirow{3}{*}{ Valid } & No, not at all & 20 & 11,9 & 11,9 & 11,9 \\
& Mostly not & 42 & 25,0 & 25,0 & 36,9 \\
& I am undecided & 30 & 17,9 & 17,9 & 54,8 \\
& Mostly yes & 36 & 21,4 & 21,4 & 76,2 \\
& Yes, completely & 40 & 23,8 & 23,8 & 100,0 \\
& Total & 168 & 100,0 & 100,0 & \\
\hline
\end{tabular}

Examining attitudes to the negative impact of non-attendance at preschool on the physical development of children led to very divided opinions The percentage of the surveyed teachers agreeing with this statement was $45.2 \%$, while $17.9 \%$ were undecided, and $36.9 \%$ of them disagreed with the statement.

\section{Table 15}

Break and inability to attend preschool can have a negative effect on children's intellectual development

\begin{tabular}{rlrrrr}
\hline & Frequency & \multicolumn{1}{c}{ Percent } & Valid Percent & $\begin{array}{c}\text { Cumulative } \\
\text { Percent }\end{array}$ \\
\hline \multirow{2}{*}{ Valid } & No, not at all & 8 & 4,8 & 4,8 & 4,8 \\
& Mostly not & 28 & 16,7 & 16,7 & 21,4 \\
& I am undecided & 36 & 21,4 & 21,4 & 42,9 \\
& Mostly yes & 60 & 35,7 & 35,7 & 78,6 \\
& Yes, completely & 36 & 21,4 & 21,4 & 100,0 \\
& Total & 168 & 100,0 & 100,0 & \\
\hline
\end{tabular}

The percentage of the respondents who believe that the prevention of attending a preschool institution negatively affects children's intellectual development was $57.1 \%$, whereas $21.4 \%$ were undecided, and $21.5 \%$ of the surveyed teachers disagreed with the statement. 
Table 16 development

Break and inability to attend preschool can have a negative effect on children's emotional

\begin{tabular}{llrrrr}
\hline & Frequency & Percent & Valid Percent & Cumulative Percent \\
\hline \multirow{2}{*}{ Valid } & No, not at all & 8 & 4,8 & 4,8 & 4,8 \\
& Mostly not & 20 & 11,9 & 11,9 & 16,7 \\
& I am undecided & 50 & 29,8 & 29,8 & 46,4 \\
& Mostly yes & 40 & 23,8 & 23,8 & 70,2 \\
& Yes, completely & 50 & 29,8 & 29,8 & 100,0 \\
& Total & 168 & 100,0 & 100,0 & \\
\hline
\end{tabular}

When it comes to the attitudes of teachers to negative impact of not attending preschool, opinions are uneven. One third of teachers are hesitant in agreeing with this statement, $53.6 \%$ believe that there is a negative impact on the emotional development of children due to the physical impossibility of attending preschool, while $16.7 \%$ gave a negative interpretation.

\section{Discussion}

\section{Attitudes of teachers to changes in educational work during the state of emergency}

The analysis of the results determined that the teachers have enough strength and will to adequately adapt to the new circumstances. Three-quarters of the surveyed teachers said that they are positive about the changes in educational work caused by Covid-19. These results support the conclusion of the research that ,,teaching community is mentally prepared to adapt to new and innovative ways of imparting knowledge, provided their institutions well support them" (Alea et al., 2020, 141). A good adaptation of teachers to new situations by teachers does not necessarily mean that the quality of educational work will be effective. This statement is followed by the results on the quality of educational work during the state of emergency, which show that a significantly smaller number of the respondents, compared to the previous claim, believe that the quality of educational work was good. Only about half of the respondents think that the quality of educational work in that period was good. The results leave a lot of room for identifying factors that need to be improved. That the quality of distance educational work during the state of emergency can be questioned is also shown by the results of research (Edwards, 2020) which point out that $77 \%$ of surveyed parents believe that their children learned very little or nothing after the closure of educational institutions.

An attempt to determine whether the teachers share of family responsibilities increased, which badly affected their professional work during the state of emergency, indicated that slightly more than a quarter of teachers $(28.6 \%)$ had professional problems due to new family obligations. Also, slightly less than a quarter of respondents (23.8) pointed out that they needed professional support in performing work tasks during the state of emergency. The results lead us to the position that the teacher should be observed with respect for his personality and needs.

When it comes to collegiality between teachers and their mutual support, the results show the great importance of collegiality among teachers. Shah (Shah, 2012) emphasizes collegiality as an unavoidable factor in adapting to new circumstances of the modern age, and that the quality of collegiality depends on the efficiency of professional development, learning, and organizational efficiency. The cooperative relationship between teachers implies "open mutual communication, realization of the communication plan as well as work on creating ways to support children's learning and development". (Flottman, McKernan, and Tayler, 2011,6) The obtained results confirm these allegations by the fact that the vast majority of teachers $(75 \%)$ received help from colleagues in solving problems in practice, which indicates that the quality of collegiality in solving problems in practice has significant driving force. The collaboration of teachers in solving problems in practice gives a positive tone.

\section{Attitudes of teachers to cooperation with parents}

Understanding the causal link between the appearance of Covid-19, the closure of educational institutions and the interruption of the learning process, the authors (Huang et al., 2020) emphasize the need for an online way of work as an alternative. The same authors point out spatial and temporal flexibility, one of the important characteristics of online learning during the state of emergency, whose 
efficiency determines the existence of active learning. The results of the research we conducted show that the teachers had flexible working hours during the state of emergency, adapting to the new requirements in practice. The majority of the respondents $(81 \%)$ pointed out that during the state of emergency they had engagements outside the working hours provided for that. When it comes to the relationship between parents and teachers, the results speak in favor of the formation of positive cooperation. Teachers and parents are given new roles in which, in a way, the responsibility for educational work largely passes to the parents. The involvement of parents in this way of working has increased.

Another important precondition for quality educational work is the cooperation of teachers and parents. When it comes to that cooperation, the majority of respondents, $89.3 \%$ of them, agree that the parents followed their guidance and counseling during the online educational work. Also, $85.7 \%$ of teachers are satisfied with the quality of cooperation they have established with their parents. These results contribute to the opinion that teachers as well as parents understood their responsibility and role and that they accordingly contributed to the online educational process by pointing out the respect for the principle of cooperation. However, despite such satisfactory cooperation, when it comes to the role of parents in terms of compensating for the educational effect that teachers can provide to children, opinions are divided. About two-fifths (42.9\%) of the respondents believe that the parents adequately compensated for the educational effect that the teachers could not provide to the children during the state of emergency.

\section{Attitudes of teachers to the influence of impossibility of physical attendance at a preschool institution on the development of children}

An unavoidable determinant of child development is the continuity of that process. Some reports predict that the closure of educational institutions and the transition to distance learning will have longerterm consequences for children than the unfavorable epidemiological situation itself will last (Edwards, 2020).

That the organization of online activities shows weaknesses is also indicated by the results we have reached. The majority of the surveyed teachers $(63.1 \%)$ believe that the physical impossibility of attending preschool can have a bad effect on the continuous development of children, and more than half of the respondents $(55.9 \%)$ are of the opinion that the change in work caused by the emergency can also have negative influence on the achievements of children. The results indicate the necessity of physical attendance at the preschool institution, and if the epidemiological situation does not allow it, then the organizational models of online activities must be redefined and reorganized in a way that will have as few negative effects as possible.

Having in mind the need for a general aim of education, which is a versatile personality, we tried to examine the attitudes of teachers towards how the prevention of attending preschool can affect children's social, moral, physical, intellectual and emotional development. Some reports state that the influence of Covid-19 has left negative traces when it comes to exercising the rights of the child, including the right to the development of the child (Dulieu and Burgess, 2020). In order to determine which sphere of children's developmental potentials can be most negatively affected by physical non-attendance of preschool, it was found that the surveyed teachers believe that the children's social development can be most badly affected while the physical development of children is the least badly affected. The results show that the developmental potentials and goals of educational work are limited by the new emergency situation. The order of spheres of a child's development according to the significance of the negative impact are arranged on the basis of their arithmetic mean: social development (3.91), emotional development (3.61), moral development (3.55), intellectual development (3.53), physical development (3.2\%). According to the teachers, children have largely been deprived of educational activities within which they can actualize their needs for versatile development.

\section{Conclusion}

The conducted research focuses on the perception of the described problems from the perspective of teachers, which is why the conclusion making is conditioned by that fact. We tried to establish the potential problems that teachers encounter in the implementation of educational work at a distance during the state of emergency. For a more complete view of the problem, it is necessary to examine parents and try to determine the achievements of children during the state of emergency.

Based on the expressed attitudes of teachers, we can conclude that the continuous development of children during the state of emergency was slowed down. The quality of realized online activities is not at a satisfactory level and there is a lot of room for improvement. Teachers see themselves in this process 
as an adaptable and flexible practitioners who receive support for solving problems in practice from their colleagues. Quality cooperation between parents and teachers also contributes to overcoming difficulties, because mutual achievements determine the purposefulness of the educational process. The answers of the teachers lead us to the conclusion that a good part of the social, moral, intellectual, physical and emotional development of the children in the period of emergency, was not affected by the educational influence.

When it comes to the quality and quantity of goals and outcomes of children's educational development, they should certainly not be reduced, but it is necessary to adapt curricula and their implementation to new circumstances and adapt to new ways of working, looking for alternative ways and relying on acquired competencies. It is proposed to introduce new, more comprehensive organizational models of work with platforms that can be used by both teachers and parents and that will be adjusted to children. The necessity for the existence of a program of support for teacher as well as a program of support for parents and children is also pointed out. In this way, the goals and tasks of educational work can be operationally applicable and serve the purpose of the best interest of children as an unconditional commitment.

\section{Acknowledgments}

The author expresses his gratitude to the directors of preschool institutions throughout the Republic of Serbia and his colleagues who provided support in the implementation of the research. The author would like to express his deep gratitude to preschool teachers who made this study possible.

\section{Conflict of interests}

The author declare no conflict of interest.

\section{References}

Alea, L. A., Fabrea, M. F., Roldan, R. D. A., \& Faroogi, A. Z. (2020). Teachers' Covid-19 awareness, distance learning education experiences and perceptions towards institutional readiness and challenges. International Journal of Learning, Teaching and Educational Research, 19(6), 127-144. https://doi.org/10.26803/ijlter.19.6.8

Bao, X., Qu, H., Zhang, R., \& Hogan, T. P. (2020). Literacy Loss in Kindergarten Children during COVID-19 School Closures. https://doi.org/10.31235/osf.io/nbv79

Barnett, W. S., \& Jung, K. (2020). Understanding and responding to the pandemic's impacts on preschool education: What can we learn from last spring?. National Institute for Early Education Research. Retrieved from https://nieer.org/wpcontent/uploads/2020/11/NIEER_Special-Report_July_2020_What_Can_We_Learn_From_Last_Spring_UPDATED_ August 2020.pdf

Brooks, S. K., Webster, R. K., Smith, L. E., Woodland, L., Wessely, S., Greenberg, N., \& Rubin, G. J. (2020). The psychological impact of quarantine and how to reduce it: rapid review of the evidence. The Lancet 395(10227), 912-920. https://doi. org/10.1016/S0140-6736(20)30460-8

Dulieu, N. and Burgess, M. (2020). The hidden impact of COVID-19 on child rights. London, Save the Children International. Retrieved from https://resourcecentre.savethechildren.net/node/18174/pdf/the_hidden_impact_of_covid-19_on_ child_rights.pdf

Edwards J., (2020), Protect a generation, The impact of COVID-19 on children's lives. London, Save the Children International. Retrieved from https://resourcecentre.savethechildren.net/node/18218/pdf/vr59-01_protect_a_generation_report_ en $0 . p d f$

Flottman, R., McKernan, A., \& Tayler, C. (2011). Victorian Early Years Learning and Development Framework Evidence Paper. Practice Principal 2: Partnerships with Professionals, 24. Melbourne Graduate School of Education. Retrieved from https://www.education.vic.gov.au/Documents/childhood/providers/edcare/pracpartner.pdf

Gaudreau, C., King, Y. A., Dore, R. A., Puttre, H., Nichols, D., Hirsh-Pasek, K., \& Golinkoff, R. M. (2020). Preschoolers benefit equally from video chat, pseudo-contingent video, and live book reading: implications for storytime during the Coronavirus pandemic and beyond. Frontiers in Psychology, 11, 2158. https://doi.org/10.3389/fpsyg.2020.02158

Gyimah, N. (2020). Assessing technological innovation on education in the world of coronavirus (COVID-19). https://dx.doi. org/10.2139/ssrn.3670389

Huang, R. H., Liu, D. J., Tlili, A., Yang, J. F., \& Wang, H. H. (2020). Handbook on facilitating flexible learning during educational disruption: The Chinese experience in maintaining undisrupted learning in COVID-19 Outbreak. Beijing: Smart Learning Institute of Beijing Normal University. Retrieved from http://www.alecso.org/nsite/images/pdf/1-4-2.pdf

Muller, M., \& Baum, A. C. (2020). The Code and COVID-19. YC Young Children, 75(4), 72-77. Retrieved from https://search. proquest.com/openview/e7819add8480d05991134bab3f26d928/1?pq-origsite=gscholar\&cbl=27755

NEPC, (2020). The pandemic and preschool education in five chart. Retrieved from http://nieer.org/wp-content/uploads/2020/09/ NEPCPandemicin5Slides.pdf

NIEER, (2020). America's preschoolers lose important learning opportunities sue to pandemic, Raising concerns for the future. Retrieved from http://nieer.org/wp-content/uploads/2020/07/News-Release-Preschoolers-Lose-LearningOpportunities-During-Pandemic.pdf

OMEP Executive Committee, World Organisation for Early Childhood Education (2020). OMEP Position Paper: Early Childhood 
Education and Care in the Time of COVID-19. International Journal of Early Childhood, 52, 119-128. https://doi. org/10.1007/s13158-020-00273-5

Shah, M. (2012). The importance and benefits of teacher collegiality in schools-A literature review. Procedia-Social and Behavioral Sciences, 46, 1242-1246. https://doi.org/10.1016/j.sbspro.2012.05.282

UNICEF, (2020). Istraživanje o uticaju pandemije Covid-19 na porodice sa decom u Srbiji [Research on the impact of the Covid-19 pandemic on families with children in Serbia]. Retrieved from https://www.unicef.org/serbia/media/15466/file/ Istra\%C5\%BEivanje \%200\%20uticaju\%20pandemije\%20Covid-19\%20na\%20porodice $\% 20$ sa $\% 20$ decom $\% 20$ u $\% 20$ Srbiji.pdf

Закон о предшколском васпитању и образовању [Law on Preschool Education], Службени гласник, бр.10/19. 
